MARCIN BROL

\title{
WSPÓŁCZESNE PROBLEMY KRAJÓW AFRYKI PÓŁNOCNEJ A JAKOŚĆ SEKTORA PUBLICZNEGO
}

\begin{abstract}
WSTĘP
Kraje Afryki Północnej stały się w 2011 roku przedmiotem zainteresowania społeczności międzynarodowej za sprawą gwałtownych konfliktów wewnętrznych, które doprowadziły do zmian politycznych. Konsekwencją niepokojów był gwałtowny wzrost cen surowców naturalnych, takich jak gaz i ropa naftowa, w które obszar ten obfituje. Dodatkowo doprowadzily one do wstrzymania ruchu turystycznego z Europy i uruchomienia strumienia migracji w odwrotnym kierunku w stronę Europy, głównie południowego wybrzeża Włoch. Kraje takie jak Egipt, Tunezja, Libia, Maroko czy Algieria, ze względu na swoje położenie, od wieków leżały w sferze zainteresowania swoich północnych sąsiadów, a obecnie są ważnymi partnerami ekonomicznymi krajów Unii Europejskiej. Przez dziesięciolecia bogate i demokratyczne kraje europejskie tolerowały autorytarny styl rządów i represje polityczne, które w krajach tych były stosowane powszechnie, ze względu na niechlubną przeszłość kolonialną i konieczność zapewnienia stabilności dostaw surowców energetycznych.

W krajach Afryki Północnej sektor publiczny nie rozwinął się w taki sposób jak w krajach europejskich. Jego ułomność przejawia się z jednej strony w sposobie gospodarowania środkami publicznymi, które w znacznej mierze zostały sprzeniewierzone przez rządzących lub przeznaczone na finansowanie aparatu represji gwarantującego utrzymanie się przy władzy. $Z$ drugiej strony wyrazem jego słabości jest niezadowolenie społeczne, które doprowadziło do serii przewrotów społecznych. Celem niniejszej pracy jest przedstawienie i uporządkowanie stanu wiedzy dotyczącej funkcjonowania sektora publicznego w krajach Afryki Północnej, a także zidentyfikowanie czynników, które doprowadziły do rewolty w 2011 roku. Autor stawia tezę, że niepokoje społeczne w omawianych krajach
\end{abstract}


były skutkiem słabości sektora publicznego. Jednocześnie stwierdzić należy, że poprawa jakości jego funkcjonowania może nastąpić jedynie w wyniku demokratyzacji i zwiększenia jego transparentności.

\section{CHARAKTERYSTYKA KRAJÓW PÓŁNOCNOAFRYKAŃSKICH}

Do krajów Afryki północnej zalicza się kraje Maghrebu, czyli Maroko, Tunezję, Algierię, Saharę Zachodnią, Mauretanię oraz Libię, a także Sudan i Egipt. Słowo maghreb w języku arabskim oznacza „zachód” i tradycyjnie stosowane było w odniesieniu do najbardziej na zachód wysuniętych krajów kultury islamskiej. W roku 1989 doszło do znacznego zbliżenia krajów tego regionu. Wtedy powołano bowiem do życia Arabską Unię Maghrebu (Ittihad al-Maghrib al-Araby). Głównym celem organizacji jest gospodarcza i - w mniejszym stopniu - polityczna integracja państw członkowskich. Jednakże z powodu sporu Algierii i Maroka o status Sahary Zachodniej funkcjonowanie organizacji jest mocno utrudnione i wielokrotnie dochodziło do odwoływania szczytów organizacji ${ }^{1}$. Egipt i Sudan nie należą do Unii, lecz ze względu na wiele powiązań z krajami Maghrebu w opracowaniach międzynarodowych rozpatrywane są zazwyczaj jako jeden subregion. Wśród cech wspólnych krajów Afryki Północnej wymienić należy:

- kulturę islamską (sunnicką),

- położenie i warunki geograficzne,

- duże wpływy polityczne i gospodarcze Europy,

- podobny system polityczny (autorytarny).

Wymienione kraje charakteryzują się ścisłymi stosunkami politycznymi i gospodarczymi z Europą. Jest to konsekwencją zarówno położenia geograficznego, ale również przeszłości kolonialnej. Większość tego obszaru przez wiele wieków była we władaniu Imperium Osmańskiego, którego rozpad zapoczątkował zajęcie poszczególnych terytoriów przez europejskie potęgi kolonialne. Algieria, Tunezja i Maroko zależne były do lat 1956-1962 od Francji. Język francuski jest tam powszechnie używany do dzisiaj, a wiele wzorców kulturowych sprowadzonych przez kolonizatorów przyjęło się w miejscowej kulturze (od sposobu ubierania, poprzez nawyki kulinarne, po zainteresowania sportowe). Libia do zakończenia II wojny światowej była kolonią włoską, natomiast Egipt będący protektoratem Wielkiej Brytanii uzyskał niepodległość w 1922 roku, lecz pozostawał pod faktycznym wpływem Brytyjczyków do 1952 roku². Można zatem zaryzykować twierdze-

1 F. Aggad, The Arab Maghreb Union: Will the Haemorrhage Lead to Demise?, „African Insight”, April 6, 2004.

2 D.E. Long, B. Reich, M. Gąsiorowski, The Government and Politics of the Middle East and North Africa, Westview Press, New York 2010. 
nie, że obecna sytuacja gospodarcza i polityczna w pewnym stopniu zależna jest od doświadczeń związanych z okresem kolonialnym. Należy także zauważyć, że dawni protektorzy starają się być aktywni na scenie politycznej i gospodarczej. Dotyczy to w szczególności Francji, która stała się głównym partnerem handlowym i jest stronnikiem Algierii, Maroka i Tunezji w kontaktach z Unią Europejską, a także Włoch, które są głównym odbiorcą libijskiego gazu i ropy, za sprawą rurociągu Greenstream i sześciu terminali naftowych ${ }^{3}$.

Inną cechą charakterystyczną krajów północnej Afryki jest wysoki przyrost naturalny. Rocznie liczba ludności rośnie w tym regionie o 1,7\%, przy średniej światowej 1,2\% i europejskiej równej zero. Skutkiem tego był wzrost populacji ze 175 milionów w roku 2000 do 202 milionów w roku 2007 (według danych ONZ). W Egipcie osoby poniżej 25 roku życia stanowią aż 52,3\% populacji, w Maroku 47,7\%, w Algierii 47,4\%, w Libii 47,4\%, a w Tunezji 47,7\% ${ }^{4}$. Niestety brak tak szczegółowych danych dla Sudanu i Sahary Zachodniej, lecz według szacunków ONZ odsetek osób w tym wieku wynosi tam pomiędzy 45\% a 55\%. W wyniku szybkiego przyrostu liczby ludności i kryzysu globalnego, lokalne rynki nie zdołały wykreować wystarczającej liczby miejsc pracy, co z kolei spowodowało gwałtowny wzrost bezrobocia w tej grupie wiekowej. Według szacunków ONZ w Tunezji odsetek bezrobotnych wśród młodych osób przekroczył 30\%. Należy mieć tu na uwadze również uwarunkowania kulturowe, charakterystyczne dla społeczeństw islamskich. Tradycyjnie kobiety nie powinny pracować, lecz zajmować się domem, w związku z czym nie zgłaszają one podaży pracy i nie są uwzględnianie w statystykach. Gdyby tak się stało, odsetek bezrobotnych wzrósłby znacząco. Podsumowując powyższy wywód, wskazać należy na najważniejszą konsekwencję takiego stanu rzeczy - niepracujący młodzi mężczyźni nie są w stanie zaspokoić potrzeb materialnych swojej szybko rosnącej rodziny.

Najważniejszymi gałęziami gospodarki krajów północnoafrykańskich jest przemysł wydobywczy i turystyka. Zgodnie z islamem, państwu przynależna jest pewna własność, dzięki której rozwiązuje ono problemy społeczne. Osoby indywidualne mogą posiadać każdą własność, z wyjątkiem tego, co zalicza się do własności publicznej lub rzeczy zakazanych (np. alkohol i wieprzowina). Własność publiczną stanowią wszystkie surowce naturalne (np. ropa naftowa i gaz ziemny) oraz dobra, które się współdzieli z innymi członkami społeczności (np. oceany, morza, rzeki, drogi) $)^{5}$. W związku z tym wszystkie bogate złoża znajdujące się w omawianych krajach należą do władz państwowych. To samo dotyczy Kanału Sueskiego, który stanowi jedno z głównych źródeł dochodu Egiptu. Sprawowanie

\footnotetext{
Country Analysis Briefs - Libya, U.S. Energy Information Administration, Washington, February 2011.

P. Sasnal, Wiek przebudzenia, Tygodnik „Polityka”, nr 7(2794), 12 lutego 2011.

5 K. Armstrong, Krótka historia islamu, Wydawnictwo Dolnośląskie, Wrocław 2004.
} 
i utrzymanie władzy w krajach arabskich jest więc zadaniem niezwykle pożądanym, daje bowiem olbrzymie możliwości finansowe. Przynależność do sfery rządzących przynosić może także znaczne korzyści indywidualne. Wiąże się to z innym charakterystycznym zjawiskiem dla omawianej grupy krajów, czyli sposobem sprawowania władzy. We wszystkich państwach północnoafrykańskich władzę sprawuje od wielu lat ta sama osoba, która stery w państwie przejęła albo w wyniku zamachu stanu, albo odziedziczyła władzę po członku swojej rodziny. Sytuację polityczną w tej części świata w skrócie nazwać można niestabilną. I to nie w rozumieniu europejskim, gdzie niestabilność polityczna oznacza problem ze sformowaniem większości parlamentarnej. Brak stabilności w tym przypadku oznacza istnienie uzbrojonych grup o charakterze partyzanckim lub terrorystycznym. Dotyczy to w szczególności Sudanu, Sahary Zachodniej, Algierii i Egiptu, ale także Tunezji, gdzie również dochodziło do zamachów terrorystycznych. Niekwestionowanym liderem w długości rządów jest Muammar Kaddafi, który władzę w Libii sprawuje od 1969 roku. Hosni Mubarak na czele Egiptu stał od 1981 roku, Zin Al-Abidin Ben Ali rządził Tunezją od 1987 roku, a Omar Al-Bashir rządzi Sudanem od 1989 roku. Stosunkowo krótko, bo od 1999 roku władzę w Algierii sprawuje Abdelaziz Bouteflika, a w Maroku król Mohammed IV. Jednak jak na europejskie standardy polityczne ich rządy trwają bardzo długo. Jest to wynikiem braku kadencyjności. Jeśli nawet organizowane są wolne wybory, to dotyczą one co najwyżej składu parlamentu. W dodatku są one najczęściej w sposób jawny lub półjawny fałszowane. Najczęściej listy wyborcze są ustalane w porozumieniu z rządzącym władcą, który wskazuje zaufanych ludzi. Sam przy tym jest nieodwoływalny i funkcję swoją pełni dożywotnio.

\section{PROBLEM EFEKTYWNOŚCI SEKTORA PUBLICZNEGO}

Sektor publiczny funkcjonuje po to, aby zaspokajać zbiorowe potrzeby społeczności w skali globalnej, narodowej, regionalnej i lokalnej. Sposób jego funkcjonowania budzi jednak wiele wątpliwości. Krytycy wskazują na biurokrację i korupcję jako źródła nieprawidłowości, upatrując w konkurencji szansę na poprawę efektywności sektora publicznego. Tymczasem biurokracja i korupcja nie są jedynymi źródłami jego zawodności, jest nim również sposób gospodarowania mieniem publicznym, wynikający z niedochodowego charakteru jednostek sektora publicznego. Do wzrostu ich efektywności przyczynić się może nie tylko konkurencja, lecz również większe zaangażowanie organizacji pozarządowych oraz większa przejrzystość i stabilność prawa.

Gospodarowanie mieniem publicznym rodzi wiele nieprawidłowości i pokus zwiększenia puli prywatnych korzyści za pośrednictwem dóbr publicznych, 
kolektywnych lub klubowych. Skoro dobra wytwarzane w sektorze publicznym nie mają jednego właściciela i są wytwarzane ze środków publicznych, to za ich pomocą można maksymalizować indywidualne korzyści. Przykładem tego może być sytuacja, w której urzędnik samorządowy korzysta ze służbowego samochodu w celach prywatnych. Osoba dysponująca mieniem publicznym nie dba zatem o koszty związane z działalnością jednostki publicznej. Sytuacja taka nie wystąpi nigdy w przypadku osoby prowadzącej własną działalność gospodarczą. W tej bowiem sytuacji zwiększenie kosztów działalności oznaczać będzie zmniejszenie zysków i indywidualnych dochodów. W sektorze publicznym suma indywidualnych dochodów pracownika nie wynika wprost z kalkulacji ekonomicznej. Gospodarowanie nie swoim mieniem nie zmusza do oszczędności. Podobną sytuację zauważyć można również w sektorze prywatnym, ale tylko tam, gdzie własność nie łączy się jednocześnie z funkcjami zarządczymi, czyli przede wszystkim w korporacjach. W tego typu przedsiębiorstwach akcjonariusze, czyli faktyczni właściciele nie mają większego wpływu na zachowania kadry menedżerskiej oraz pracowników najemnych. W konsekwencji przepłacana kadra menedżerska często pobiera pensje nieadekwatne do zakresu obowiązków, a pracownicy nie utożsamiają się z firmą, korzystając z jej majątku dla własnych potrzeb.

Zjawiskami wpływającymi niekorzystnie na jakość sektora publicznego jest nadmierne upolitycznienie, kumoterstwo i nepotyzm. W ten sposób w urzędach administracji publicznej doprowadzić można do przerostu zatrudnienia i tym samym zmniejszenia efektywności ich funkcjonowania. Kluczem do poznania przyczyn przedstawionych patologii jest poznanie motywacji, którymi kierują się pracownicy sektora publicznego oraz uwarunkowań instytucjonalnych i kulturowych. Zakładając, że każdy człowiek dąży do maksymalizacji nadwyżki korzyści nad kosztami, dojść należy do wniosku, że przedstawione zachowania są w pełni racjonalne i łatwe do przewidzenia. Mając dostęp do bezpłatnych dóbr, dzięki którym możliwe jest pełniejsze zaspokojenie potrzeb indywidualnych, naturalnym odruchem ludzkim jest wykorzystanie tych dóbr i maksymalizacja użyteczności z ich konsumpcji. Niektórzy badacze wskazują na istnienie motywów altruistycznych, objawiających się ograniczeniem konsumpcji w celu zwiększenia puli korzyści zbiorowych. Jednakże altruizm nie jest cechą trwałą, lecz występującą w krótkich okresach. Altruizm nie prowadzi bowiem do zaspokojenia potrzeb podstawowych, a jedynie potrzeb wyższego rzędu, takich jak potrzeba przynależności do grupy czy samorealizacji. Podsumowując tę część wywodu, wskazać należy na najważniejsze czynniki zmniejszające efektywność sektora publicznego, którymi są:

- korupcja,

- nadmierna biurokracja,

- wykorzystanie majątku publicznego do realizacji prywatnych interesów, 
- wykorzystanie majątku publicznego do realizacji celów partii politycznych,

- kumoterstwo i nepotyzm,

- brak przejrzystości i demokratycznych procedur.

Analizując wymienione czynniki w kontekście sytuacji północnej Afryki, zauważyć można, że w zasadzie wszystkie one charakteryzują system władzy publicznej w tej części świata. W dalszej części artykułu podjęta zostanie próba wyjaśnienia przyczyn takiej sytuacji.

\section{SEKTOR PUBLICZNY W KRAJACH PÓŁNOCNOAFRYKAŃSKICH}

W zależności od potrzeb społeczeństwa, stopnia zawodności rynku, stanu prawnego oraz czynników historycznych sektor publiczny w różnych państwach odgrywa mniej lub bardziej znaczącą rolę w procesie kształtowania rzeczywistości gospodarczej danego kraju. Jest on różny nawet w przypadku państw będących na podobnym poziomie cywilizacyjnym, działających $\mathrm{w}$ ramach ponadnarodowych struktur. Jego różnorodność przejawia się w odpowiednim dopasowaniu do potrzeb charakterystycznych dla danych społeczności. Rola państwa w krajach arabskich $\mathrm{w}$ znacznym stopniu wynika $\mathrm{z}$ tradycji i wiary. Istotnym czynnikiem kształtującym stosunki społeczne jest fakt, że większość uczestników życia społecznego to mężczyźni. Ten tradycyjny model powoduje, że przeciętna rodzina musi polegać wyłącznie na dochodach zgromadzonych w wyniku pracy mężczyzny. Innym ważnym czynnikiem jest tradycyjny sposób prowadzenia polityki ekonomicznej. Islam zakłada, że nadrzędnym celem państwa jest zabezpieczenie podstawowych potrzeb ludzi, ale też stworzenie warunków do zaspokojenia potrzeb wyższego rzędu. Mówiąc inaczej, w kulturze islamskiej bieda jest niedopuszczalna, ale nie ma też nic złego w bogaceniu się. Dlatego w tradycji islamskiej funkcjonuje podatek zwany „zakat”, który jest nie tylko rodzajem podatku, ale jedną z dróg oddawania czci Allahowi, a także jednym z filarów islamu (tak ważnym jak modlitwa). Podatek ten zobowiązany jest płacić każdy muzułmanin w zależności od posiadanego majątku6. Zasada ta wyewoluowała $\mathrm{w}$ formę bakszyszu, czyli napiwku, a raczej czegoś w rodzaju zawoalowanej jałmużny. Jest to obyczaj związany z religią islamu nakazujący wiernym dzielenie się częścią swoich dochodów z biednymi, a żeby biednego nie urazić darowizną w postaci czystej jałmużny pretekstem może być nawet symboliczna pomoc, czy zwykła uprzejmość, którą się wynagradza właśnie bakszyszem. Obecnie zwyczaj ten przybrał w krajach Afryki Północnej rozmiary niewystępujące $w$ innych krajach arabskich, między innymi ze względu na dużą liczbę turystów z Europy. Stał się łapówką, którą niejednokrotnie należy ofiaro-

\footnotetext{
6 Ibidem.
} 
wać za rzeczy, których bezpłatna dostępność wydaje się oczywista. Jednoczesna pochwała bogactwa spowodowała pęd ku bogaceniu się osób, które już uchodziły za zamożne. W ten sposób powstały klany rodzinne, które w hierarchii społecznej zajmowały najwyższe miejsca.

W ramach poszczególnych społeczeństw zaobserwować można pewne różnice w poziomie i natężeniu korupcji. Inny z całą pewnością jest „próg korupcji”, czyli wysokość nadwyżki, która skłaniałaby do zachowań korupcyjnych. Prawidłowości przedstawione w artykule odnoszą się do uniwersalnych zachowań ludzkich, jednakże to, w jakich okolicznościach zachowania takie się pojawią, nie da się jednoznacznie stwierdzić. Wynika to z wymyślonych i przyjętych przez ludzi ograniczeń, takich jak normy zachowania, konwencje, kody postępowania, czyli instytucji. Oznacza to system określonych co do formy i nieformalnych regu1 ${ }^{7}$. Te uwarunkowania powodują, że w niektórych kręgach lub też w całych społecznościach próg korupcji będzie niski i nawet niewielkie korzyści osiągnięte na tej drodze warte będą wysiłku. W innych natomiast próg ten będzie na tyle wysoki, że jedynie w przypadku wyjątkowych korzyści dojdzie do korupcji. Według badań prowadzonych przez Transparency International, wśród krajów o najniższym poziomie korupcji wskazać można rozwinięte kraje europejskie lub z kręgu kultury europejskiej. Przy czym dominują te o wysokim poziomie rozwoju gospodarczego i kulturze protestanckiej. Niżej znajdują się rozwinięte państwa o kulturze rzymskokatolickiej. Następną grupę stanowią kraje kultury islamu oraz te, które wywodzą się z byłego bloku wschodniego. Kolejną grupę stanowią biedne kraje postkolonialne - państwa afrykańskie i Azji Południowo-Wschodniej. Stawkę zamykają natomiast kraje, w których panują niepokoje społeczne: Afganistan, Irak, Myanmar i Haiti. Kwestia klasyfikacji poszczególnych krajów była wielokrotnie przytaczana $w$ literaturze przedmiotu ${ }^{8}$. Poniżej przedstawiono aktualną pozycję badanych państw $\mathrm{w}$ rankingu stworzonym na podstawie wskaźnika percepcji korupcji (CPI). Tworzony jest on na podstawie informacji dotyczących postrzegania korupcji w społeczeństwie. Nie jest zatem wskaźnikiem idealnym, gdyż jego wartości mogą zależeć od bieżącej sytuacji politycznej i zainteresowania tematem mediów. Jednakże jest on jedynym sposobem na przybliżony pomiar natężenia korupcji. Liczba 10 oznacza w tym przypadku wartość idealną - brak korupcji. W praktyce nigdy ona nie występuje. Natomiast liczba 0 oznacza, że wszystkie bez wyjątku procesy wymiany odbywają się za pomocą łapówki, W kolejnych ko-

7 K. Nowakowski, Korupcja a instytucje w gospodarce, [w:] Ead instytucjonalny w gospodarce, t. II, Wydawnictwo Uniwersytetu Mikołaja Kopernika, Toruń 2006, s. 138.

8 Por. M. Brol (red.), Zarys Ekonomii Sektora Publicznego, Wydawnictwo Uniwersytetu Ekonomicznego we Wrocławiu, Wrocław 2010; idem, Źródta zachowań korupcyjnych w państwach rozwiniętych i rozwijających się - próba porównania, [w:] Globalizacja a konkurencyjność w gospodarce śriatowej, CeDeWu, Warszawa 2008. 
lumnach podano PKB per capita oraz wartość wskaźnika „rzutu butem” (the shoe thrower's index), przygotowanego przez Economist Intelligence Unit - pracownię badawczą tygodnika „The Economist”. Jest to wskaźnik tworzony dla krajów arabskich, rządzonych w sposób niedemokratyczny. Nazwę swoją wziął od słynnego rzutu butem w byłego prezydenta Stanów Zjednoczonych Georga W. Busha. W kulturze islamskiej dotknięcie butem uważane jest za zniewagę i wyraża pogardę dla innej osoby. Im wyższa wartość (w przedziale od 0 do 100), tym wyższe prawdopodobieństwo przewrotu i niepokojów społecznych. Tworzony on jest na podstawie następujących czynników: odsetek populacji poniżej 25 roku życia, bezwzględna liczba osób w wieku poniżej 25 lat, poziom korupcji (CPI), wolność prasy (na podstawie rankingu Freedom of the Press tworzonego przez organizację Freedom House), poziom demokracji (na podstawie wskaźnika demokracji DI), PKB per capita, czas sprawowania władzy przez przywódców. W roku 2010 najwyższe prawdopodobieństwo rewolty występowało kolejno w: Jemenie, Libii, Egipcie, Syrii i Iraku.

Tabela 1. Wskaźnik percepcji korupcji, PKB per capita oraz „rzutu butem” w badanych krajach

\begin{tabular}{|c|c|c|c|c|}
\hline $\begin{array}{c}\text { POZYYA } \\
\text { W RANKINGU } \\
\text { KORUPCJ }\end{array}$ & KRAJ & CPI 2010 & $\begin{array}{c}\text { PKB PER CAPITA } \\
\text { (wg PPP, 2009, USD) }\end{array}$ & $\begin{array}{c}\text { WSKAŻNIK „RZUTU BUTEM" } \\
\text { (THE SHOE THROWER'S INDEX) } 2010\end{array}$ \\
\hline 59 & Tunezja & 4,3 & 8254 & 48 \\
\hline 85 & Maroko & 3,4 & 4604 & 49 \\
\hline 98 & Egipt & 3,1 & 6123 & 67 \\
\hline 105 & Algieria & 2,9 & 6869 & 52 \\
\hline 143 & Mauretania & 2,3 & 2037 & 56 \\
\hline 146 & Libia & 2,2 & 14328 & 71 \\
\hline 172 & Sudan & 1,6 & 2380 & b.d. \\
\hline
\end{tabular}

Źródło: Transparency International; Międzynarodowy Fundusz Walutowy; Economist Intelligence Unit.

Słabość sektora publicznego w Afryce Północnej wynika nie tylko z braku środków finansowych, lecz przede wszystkim ze sposobu sprawowania władzy. We wszystkich badanych krajach prawdopodobieństwo wystąpienia rewolty społecznej jest duże (pomiędzy 50 a 70\%, jak wynika z analizy wskaźnika „rzutu butem"). Jednocześnie są to państwa o ponadprzeciętnym udziale korupcji w procesie wymiany. Korupcja jest istotnym czynnikiem wpływającym na stabilność rządów, lecz nie jedynym. Wskaźnik CPI zamieszczony w tabeli odzwierciedla jednocześnie nastroje społeczne i sposób postrzegania sektora publicznego. Sko- 
ro korupcja występuje najczęściej pomiędzy urzędnikiem i petentem, a wskaźnik ten tworzony jest na podstawie subiektywnych odczuć obywateli, jego wartość wskazywać musi na stosunki panujące na linii władza $\rightarrow$ obywatel. Korupcja nie była też jedynym powodem niepokojów społecznych w północnej Afryce. Można powiedzieć, że była katalizatorem tych zdarzeń. Lecz to ujawnienie przez portale internetowe skali korupcji spowodowało zamieszki w Tunezji. Bardzo interesującym zjawiskiem były okoliczności, w których doszło do buntu. Przewrót w Tunezji nazywany jest niekiedy „rewolucją Wikileaks” od nazwy portalu internetowego publikującego „przecieki” z oficjalnej korespondencji dyplomatycznej, obnażające korupcję i wystawny styl życia prominentów reżimu'. Można zaryzykować stwierdzenie, że dzięki Internetowi zwiększyła się przejrzystość sfery publicznej. Na portalach takich jak Facebook i Twitter ludzie zaczęli wymieniać się doświadczeniami i obserwacjami dotyczącymi systemu politycznego i gospodarczego, w którym funkcjonują. Tradycyjne media - prasa, radio i telewizja, kontrolowane i cenzurowane przez państwo nie zapewniały takich informacji. Dodatkowo Internet stworzył możliwość porozumienia się osób niechętnych reżimowi. Dlatego jedną z pierwszych decyzji rządu Egiptu po wybuchu zamieszek było odcięcie całego kraju od sieci. Nie bez znaczenia była też determinacja i zaangażowanie społeczne, czyli cechy charakteryzujące młode społeczeństwa islamskie. Najważniejszą częścią składową wskaźnika „rzutu butem” jest udział osób poniżej 25 roku życia w populacji ogółem. Czynnikowi temu przypisano wagę 0,25. Innymi słowy można powiedzieć, że wartość tego wskaźnika w jednej czwartej zależy od tego, jaką część populacji stanowią młodzi ludzie. Wyjaśnienie tak znacznej wagi tego czynnika jest proste. Napływ młodych ludzi na rynek pracy, który nie jest w stanie wygenerować odpowiedniej liczby miejsc pracy, a w dodatku powszechnie występująca na nim korupcja i nepotyzm rodzą niezadowolenie i frustrację. Było to bezpośrednią przyczyną konfliktu w Tunezji, Egipcie i Libii. Dodatkowo sytuację tę spotęgował autorytarny sposób sprawowania rządów i brak wolności słowa.

Istnieje kilka przyczyn tego, że w krajach demokratycznych sektor publiczny działa lepiej niż w krajach niedemokratycznych. Po pierwsze jest to kadencyjność władz. Wybory stanowią bowiem weryfikację poczynań rządzących. Społeczeństwo, obserwując sposób funkcjonowania władzy, może nie przedłużyć legitymacji do sprawowania rządów, wybierając nową ekipę, a następnie obserwując jej poczynania. Taka cykliczność powoduje oczyszczenie atmosfery w sektorze publicznym. Drugim czynnikiem jest wolność słowa. Większość afer z udziałem polityków w Europie ujawniła prasa lub organizacje niepubliczne weryfikujące działania władz (tzw. watch-dogs). Brak przejrzystości sektora publicznego doprowadzić może do powstania zjawiska zwanego piramidą korupcyjną. Jest to

9 R. Stefanicki, Last minute prezydenta Ben Alego, „Gazeta Wyborcza” 24.01.2011. 
mechanizm ilustrujący sposób działania skorumpowanej administracji publicznej w krajach autorytarnych lub totalitarnych. Przepływ pieniędzy pochodzących z łapówek w tym przypadku może wyglądać następująco: nabywca usługi (obywatel) $\rightarrow$ urzędnik niższego szczebla (np. nauczyciel, lekarz) $\rightarrow$ urzędnik wyższego szczebla (np. dyrektor, minister) $\rightarrow$ pryncypał (np. prezydent, premier, dyktator). Przy czym na każdym kolejnym szczeblu suma przekazanych pieniędzy wzrasta, ponieważ urzędnik niższego szczebla obsługuje wielu obywateli, a z kolei urzędnik wyższego szczebla wielu urzędników szczebla niższego. Strumień pieniędzy ulega więc kumulacji wraz z przechodzeniem na coraz wyższe szczeble w hierarchii biurokratycznej. W krajach autorytarnych lub totalitarnych łatwiej stworzyć zasłonę, przy której dochodzi do korupcji. W sferze niejawnej urzędnik państwowy może wykorzystać posiadane zasoby i informacje w celu maksymalizacji indywidualnych korzyści za pomocą łapówki. W krajach arabskich, rządzonych w sposób autorytarny, pozbawionych wolnej prasy stało się to normą w kontaktach urzędnik $\rightarrow$ petent. W systemach demokratycznych znacznie większa część kontaktów pomiędzy obywatelem i państwem jest ściśle sformalizowana i o wiele bardziej przejrzysta, dzięki oddolnej kontroli społecznej i wolnej prasie.

W krajach niedemokratycznych więcej pieniędzy pozostaje w sferze niejawnej. Większa szara strefa oznacza niższe podatki i niższe przychody państwa. Jak wynika z przechwyconej i upublicznionej przez portal Wikileaks korespondencji zagranicznych dyplomatów rezydujących na terenie krajów północnoafrykańskich, większość wpływów z łapówek trafiała bezpośrednio do rządzących, pomnażając ich majątek ${ }^{10}$. Posiadając duże zasoby będące państwową własnością, sprawujący władzę na różnych szczeblach mieli możliwość pomnażania swojego majątku w różnoraki sposób. Jak wskazuje Transparency International, w Tunezji, Egipcie, Maroku, Algierii i Mauretanii łapówka stała się podstawowym argumentem $\mathrm{w}$ procesie poszukiwania pracy. W szczególności dotyczy to przedsiębiorstw państwowych i administracji publicznej, gdzie w zamian za łapówkę oferowano pracę, a od oferowanej kwoty zależało stanowisko i wynagrodzenie. Zjawisko to stało się na tyle powszechne, że dotyczyło nie tylko najlepiej opłacanych stanowisk, ale również tych najniższych - np. sprzątaczek. Również osoby żądające łapówek musiały je płacić swoim przełożonym na wyższych stanowiskach. W ten sposób stworzono mechanizm, w którym każdy opłacał każdego. Niemałe znaczenie miała tu tradycja bakszyszu - opłat za każdą przysługę. W Libii, najbogatszym i najbardziej zasobnym $w$ surowce naturalne $z$ analizowanych krajów, według informacji Transparency International, wpływy z handlu ropą pozostawały w wąskim gronie rządzących, a benzyna w lokalnych stacjach benzynowych była

10 J. Winiecki, Jaśminowo-internetowa, Tygodnik „Polityka”, nr 4(2791), 22 stycznia 2011. 
niedostępna ${ }^{11}$. Sytuacja gospodarcza w północnej Afryce pod wieloma względami przypomina system funkcjonujący w krajach RWPG w drugiej połowie XX wieku. Dominująca własność państwowa i indywidualne decyzje rządzących dotyczące sfery gospodarczej przywołują na myśl gospodarkę centralnie sterowaną.

W gospodarce nakazowo-rozdzielczej część negatywnych zachowań społecznych determinowały dwa czynniki. Po pierwsze przez zanik własności prywatnej na rzecz kolektywnej, a po drugie przez niewystarczającą ilość dóbr konsumpcyjnych. Jak pisał J. Kornai gospodarki wszystkich krajów socjalistycznych cechowały się permanentnym niedoborem. Chociaż niedobór ten był czasami silniejszy, a czasami słabszy, to nigdy nie wystąpił w nich stan „nadwyżkowej podaży” ${ }^{2}$. Konsekwencją niedoboru była korupcja. Według Hankissa „dopóki występuje niedobór, dopóty trzeba powierzyć komuś czynność dzielenia: urzędnikowi, sprzedawcy, sklepowemu, komuś zajmującemu odpowiednią ku temu pozycję. Ten akt powołania władzy rozdzielającej jest jednym z podstawowych warunków wstępnych powstania korupcji”"13. Powszechną praktyką było „załatwianie” artykułów niedostępnych za pomocą legalnych kanałów dystrybucji. Kwitł zatem handel „spod lady”, a stosunki pomiędzy poszczególnymi członkami społeczeństwa przypominały sieć zależności i powiązań zbudowanych na bazie drobnych uprzejmości i zobowiązań. Sieć taka charakterystyczna jest obecnie dla krajów arabskich. Konflikty, które rozpoczęły się w Tunezji, Egipcie i Libii na początku 2011 roku zostały wywołane między innymi poprzez spadek zamożności społeczeństwa, wywołany powszechną korupcją i nepotyzmem.

\section{ZAKOŃCZENIE}

Przedstawiony w niniejszym artykule sposób działania państwa uznać należy za dalece szkodliwy. Przepływ bogactwa od obywatela do władcy, poprzez system administracji publicznej prowadzi bowiem do stopniowego osłabienia instytucji państwa. To z kolei doprowadzić może do rozkładu gospodarczego, ponieważ słabe państwo nie jest w stanie pełnić swojej podstawowej funkcji „nocnego stróża” i zagwarantować tym samym dystrybucji podstawowych dóbr publicznych, jakimi są bezpieczeństwo publiczne i sprawiedliwość społeczna. Niezadowolenie społeczne wynikające $z$ większego przepływu i lepszej dostępności informacji spowodowane jest utratą zaufania obywateli do instytucji państwa. Sytuacja taka doprowadzić może nawet do anarchii lub przewrotu politycznego. Tak stało się

\footnotetext{
11 Corruption Perception Index 2010, Transparency International, Berlin 2010.

12 J. Kornai, Wzrost, niedobór, efektywnośc, PWN, Warszawa 1986, s. 37.

13 E. Hankiss, Putapki spoteczne, Wiedza Powszechna, Warszawa 1986, s. 94.
} 
na początku 2011 roku w Tunezji i Egipcie. Obywatele tych państw dość mieli samowoli swoich władców oraz kwitnącej korupcji, wyszli więc na ulice z zamiarem ich obalenia. Słabość sektora publicznego prowadzi do spadku ogólnej zamożności społeczeństwa. Konsekwencją takiego stanu rzeczy jest pogorszenie warunków życia ludności oraz pogorszenie warunków do prowadzenia działalności gospodarczej, a w konsekwencji zmniejszenie konkurencyjności gospodarki. Słabości tego sektora sprzyja brak demokracji. Kraje rządzone w sposób autorytarny przeznaczają znaczną część środków publicznych na utrzymanie władzy poprzez rozbudowany i kosztowny mechanizm opresji. Tym samym zmniejsza się pula pieniędzy, które wykorzystane mogą być w celu zaspokojenia realnych $\mathrm{i}$ istotnych potrzeb społecznych. Splot tych niekorzystnych czynników zaobserwować można w wielu krajach świata, jednak w krajach północnoafrykańskich występują dodatkowe okoliczności potęgujące ten mechanizm. Są to czynniki kulturowe, związane $\mathrm{z}$ dominującą religią, oraz historyczne, w głównej mierze wynikające z kolonialnej przeszłości.

\section{BIBLIOGRAFIA}

Aggad, F., The Arab Maghreb Union: Will the Haemorrhage Lead to Demise?, African Insight, April 6, 2004.

Armstrong K., Krótka historia islamu, Wydawnictwo Dolnośląskie, Wrocław 2004.

Brol M., Żródta zachowań korupcyjnych w pañstwach rozwiniętych i rozwijajacych się - próba porównania, [w:] Globalizacja a konkurencyjność w gospodarce światowej, $\mathrm{CeDeWu}$, Warszawa 2008.

Brol M. (red.), Zarys ekonomii sektora publicznego, Wydawnictwo Uniwersytetu Ekonomicznego we Wrocławiu, Wrocław 2010.

Corruption Perception Index 2010, Transparency International, Berlin 2010.

Country Analysis Briefs - Libya, U.S. Energy Information Administration, Washington, February 2011.

Hankiss E., Putapki spoteczne, Wiedza Powszechna, Warszawa 1986

Kornai J., Wzrost, niedobór, efektywnośc, PWN, Warszawa 1986.

Long D.E., Reich B., Gąsiorowski M., The Government and Politics of the Middle East and North Africa, Westview Press, New York 2010.

Nowakowski K., Korupcja a instytucje w gospodarce, [w:] Ead instytucjonalny w gospodarce, t. II, Wydawnictwo Uniwersytetu Mikołaja Kopernika, Torun 2006.

Sasnal P., Wiek przebudzenia, Tygodnik „Polityka”, nr 7(2794), 12 lutego 2011.

Statistical Yearbook (Fifty-third issue), United Nations Statistics Division, Statistical Dissemination Section, New York 2010.

Stefanicki R., Last minute prezydenta Ben Alego, „Gazeta Wyborcza” 24.01.2011.

Winiecki J., Jaśminowo-internetowa, Tygodnik „Polityka”, nr 4(2791), 22 stycznia 2011. 


\section{CURRENT PROBLEMS OF NORTH AFRICAN COUNTRIES AS REGARDS TO PUBLIC SECTOR PERFORMANCE}

SUMMARY

The aim of this paper is to present the North African public sector. In this paper the author also points out factors that led to revolution in 2011. Analysis is based on factors such as: corruption, nepotism and economic inefficiency. The main thesis of this study is that a weak public sector is responsible for social disorder. Improvement of this sector is only possible as a result of democratization. 
